\title{
Swimming exercise to control precocious maturation in male seabass (Dicentrarchus labrax)
}

\author{
Marco Graziano ${ }^{1,2 \dagger}{ }^{+}$Raul Benito ${ }^{1,2 \dagger}$, Josep V. Planas $^{1}$ and Arjan P. Palstra ${ }^{2,3^{*}}$
}

\begin{abstract}
Background: Male European seabass, already predominant ( 70\%) in cultured stocks, show a high incidence (20-30\%) of precocious sexual maturation under current aquaculture practices, leading to important economic losses for the industry. In view of the known modulation of reproductive development by swimming exercise in other teleost species, we aimed at investigating the effects of sustained swimming on reproductive development in seabass males during the first year of life in order to determine if swimming could potentially reduce precocious sexual maturation.

Methods: Pre-pubertal seabass (3.91 $\pm 0.22 \mathrm{~g}$ of body weight $(\mathrm{BW}))$ were subjected to a 10 week swimming regime at their optimal swimming speed $\left(\mathrm{U}_{\mathrm{opt}}\right)$ in an oval-shaped Brett-type flume or kept at rest during this period. Using Blazka-type swim tunnels, $U_{\text {opt }}$ was determined three times during the course of the experiment: $0.66 \mathrm{~m} \mathrm{~s}^{-1}$ at $19 \pm 1 \mathrm{~g} \mathrm{BW}, 10.2 \pm 0.2 \mathrm{~cm}$ of standard length (SL) (week 1); $0.69 \mathrm{~m} \mathrm{~s}^{-1}$ at $38 \pm 3 \mathrm{~g} \mathrm{BW}, 12.7 \pm 0.3 \mathrm{~cm} \mathrm{SL}$ (week 5), and also $0.69 \mathrm{~m} \mathrm{~s}^{-1}$ at $77 \pm 7 \mathrm{~g} \mathrm{BW}, 15.7 \pm 0.5 \mathrm{~cm} \mathrm{SL}$ (week 9). Every 2 weeks, size and gonadal weight were monitored in the exercised $(N=15)$ and non-exercised fish $(N=15)$. After 10 weeks, exercised and non-exercised males were sampled to determine plasma 11-ketotestosterone levels, testicular mRNA expression levels of genes involved in steroidogenesis and gametogenesis by $\mathrm{qPCR}$, as well as the relative abundance of germ cells representing the different spermatogenic stages by histological examination.

Results: Our results indicate that sustained swimming exercise at $\mathrm{U}_{\text {opt }}$ delays testicular development in male European seabass as evidenced by decreased gonado-somatic index, slower progression of testicular development and by reduced mRNA expression levels of follicle stimulating hormone receptor (fshR), 3-beta-hydroxysteroid dehydrogenase

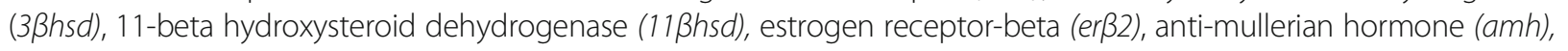
structural maintenance of chromosomes protein 1B (smc1 $\beta$ ), inhibin beta A (inhba) and gonado-somal derived factor 1 ( $g$ sdfi) in exercised males as compared with the non-exercised males.
\end{abstract}

Conclusions: Swimming exercise may represent a natural and non-invasive tool to reduce the incidence of sexually precocious males in seabass aquaculture.

Keywords: Aquaculture, Fish endocrinology, Precocious maturation, Puberty, Optimal swimming speed

\footnotetext{
*Correspondence: arjan.palstra@wur.nl

${ }^{\dagger}$ Equal contributors

${ }^{2}$ Wageningen Marine Research, Wageningen University \& Research,

Korringaweg 5, 4401, NT, Yerseke, The Netherlands

${ }^{3}$ Wageningen Livestock Research, Wageningen University \& Research Animal

Breeding and Genomics, PO Box 338, 6700, AH, Wageningen, The

Netherlands

Full list of author information is available at the end of the article
}

(c) The Author(s). 2018 Open Access This article is distributed under the terms of the Creative Commons Attribution 4.0 International License (http://creativecommons.org/licenses/by/4.0/), which permits unrestricted use, distribution, and reproduction in any medium, provided you give appropriate credit to the original author(s) and the source, provide a link to the Creative Commons license, and indicate if changes were made. The Creative Commons Public Domain Dedication waiver (http://creativecommons.org/publicdomain/zero/1.0/) applies to the data made available in this article, unless otherwise stated. 


\section{Background}

A common feature shared by all juvenile vertebrates is the quiescent state of activity of the brain-pituitarygonad (BPG) axis that characterizes the post-embryonic developmental period until the onset of puberty. Puberty is then characterised by the first spermatogenic event in males and the start of vitellogenesis in females [1]. In teleosts, the general scheme that drives puberty (GnRH/ $\mathrm{LH}-\mathrm{FSH} / \mathrm{sex}$ steroids) is well understood but the factors that trigger the shift from an inactive to a competent BPG axis are not yet fully explained [2-5]. Metabolic signals and environmental stimuli are known to play a fundamental role in triggering puberty $[3,6]$. The identification of the exact factors that regulate the onset of puberty in teleosts could have major implications for the aquaculture industry. Early gonadal maturation is a relevant problem in several commercially important species such as Atlantic salmon (Salmo salar) [7], sea bream (Sparus aurata) [8], flatfishes [9], Tambaqui [10] and European seabass (Dicentrarchus labrax) [11, 12]. In seabass aquaculture, the high incidence (20 to 30\%) of precocious sexual maturation in males during the first year of life places a critical restraint to production parameters. In this gonochoristic species, wild males normally reach puberty after the second year of life $[2,13]$. Precocious maturation of males, already predominant in the fish stock (up to 70\%), results in non-marketable fish due to the fact that growth and feed utilization are negatively affected by the energy invested in the production of gametes. Moreover, seabass precocious males have shown to exhibit lower sperm quality and viable milt production as compared to normal-maturing ones [14], thus affecting the fertilization success. Consequently, they reduce the availability of offspring from a given broodstock and create an impact on breeding programs and management in both research-related and commercial aquaculture.

In the last 10 years, efforts to modulate the onset of puberty in seabass have focused on manipulating the photoperiod. Seabass males subjected to manipulated photoperiod for 12 months after hatching show a decreased incidence of precocious maturation [13] resulting in a major investment in somatic growth [15]. In addition, it has recently been reported that in this species there is a definite temporal window (200 days after hatching) when the pineal gland is responsive to photoperiod manipulation and gametogenesis takes place [16]. Although photoperiod manipulation is effective, it may be not efficient in terms of commercial applications (e.g. high economic expenditure, difficult to apply in semi extensive and extensive aquaculture systems). Thus, other methods to control the onset of puberty in this species may be more applicable.

In other species, such as the European eel (Anguilla anguilla) and the rainbow trout (Oncorhynchus mykiss), swimming affects the beginning of puberty $[17,18]$. At the end of its life, the European eel embarks on a $6000-\mathrm{km}$ reproductive homing migration from the European coasts to the spawning ground in the Sargasso Sea. In autumn, the eels swim downstream the rivers and then enter the sea while they may be old but still in a pre-puberistic state [9] Eel represents a complex model for sexual maturation as swimming exercise in seawater suppresses hepatic vitellogenesis [18] while spermatogenesis is stimulated [19]. Also in migratory rainbow trout, swimming exercise suppressed vitellogenesis [17]. As shown by these examples, a reproductive delay, as induced by exercise, may extend the period of growth and prevent the occurrence of precocious sexual maturation. Swimming exercise may thus represent a way to significantly control puberty in farmed fish [20].

However, no information is available on the possible modulatory effects of swimming on sexual maturation in seabass. Therefore, in this study we have investigated the effect of long-term swimming exercise on gonadal development in male European seabass.

\section{Methods}

\section{Fish and conditions}

The experiments were performed at the fish facility of Wageningen Marine Research, formerly IMARES (Yerseke, The Netherlands). Juvenile seabass (Dicentrarchus labrax) $(N=1000 ; 3.91 \pm 0.22 \mathrm{~g}$ of body weight (BW) [mean \pm SEM] ; range 2.09-6.68 g) were purchased from a commercial hatchery (Ecloserie Marine de Gravelines, Gravelines, France). Upon arrival at the facilities, fish were transferred to three $800 \mathrm{~L}$ circular tanks, connected as a single Recirculating Aquaculture System (RAS) supplied with filtered natural seawater from the Oosterschelde estuary (salinity: $30.1 \%$; pH: 7.7) that was heated to a temperature of $25{ }^{\circ} \mathrm{C}$ (water renewal rate: $20-30 \%$ per week). Fish were kept under $18 \mathrm{~L} / 6 \mathrm{D}$ photoperiod and were fed three times per day on commercial $1.5 \mathrm{~mm}$ dry pellets (Skretting Perla MP: 50\% crude protein, 15\% crude fat, $2.3 \%$ fiber, $10 \%$ ash, $2 \%$ calcium, $0.7 \%$ sodium, $1.5 \%$ phosphor) ad libitum. Light intensity at the water surface was 40-50 lx. Experiments were started after 1 month of acclimatisation.

\section{Swimming training in the swim flume}

Juvenile seabass were subjected to a 10-week swimming training experiment in a $3600 \mathrm{~L}$ oval-shaped Brett-type flume $(3.0 \times 2.0 \times 1.0 \mathrm{~m})$ [21], located in a $100 \mathrm{~m}^{2}$ airconditioned room kept at $20{ }^{\circ} \mathrm{C}$. The flume was operated as RAS like the three $800 \mathrm{~L}$ tanks and every hour the entire water volume of the flume was pumped over a drum filter (model HDF 501-1P, Hydrotech AB, Vellinge, Sweden), subsequently through a trickle filter (model Fleuren and Nooijen BV, Nederweert, the Netherlands), 
through a $200 \mathrm{~L}$ biological moving bed biofilm reactor (MBBR), through a protein skimmer (model Sander Aquarientechnik, Uetze-Eltze, Germany) and finally into a $400 \mathrm{~L}$ sump before being pumped again into the flume. Water from the sump was continuously pumped via a bypass over a UV-filter (type Proclear UV30 Advantage, Tropical Marine CenterLtd. Hertfordshire, UK) and a heat exchanger (Maxicool XGL18HDA, Maxicool BV, Wessem, the Netherlands, modified by Climate4u.nl, Valkenswaard, The Netherlands) in order to reduce bacterial load and maintain a stable temperature profile, respectively. The flume was described in detail by Palstra et al. [22]. In short, on one of the straight ends, a compartment $(200 \times 70 \mathrm{~cm})$ was created by two mesh fences of green polyester coated steel (11 mm mesh size) that was then divided in two parallel sub compartments by a PVC sheet (10 mm thick), thus each measuring $200 \mathrm{~cm}$ in length (x), $35 \mathrm{~cm}$ in width (y) and $70 \mathrm{~cm}$ in depth (z) with a total volume of $525 \mathrm{~L}$. The inner sub-compartment housed the resting fish $(N=100)$ and a water flow was produced by a pump (Aqua Ocean Runner OR 6500, Aqua Medic, Loveland, CO, USA) just in order to secure good water quality. The outer sub-compartment housed the swimming fish $(\mathrm{N}=100)$ where a basic water flow was generated by a Speck pump (Badu 90/13, $0.55 \mathrm{~kW}$ with a $13 \mathrm{~m}^{3} \mathrm{~s}^{-1}$ capacity; Speck Pumps, Jacksonville, USA). The additional water flow to force fish to swim at their optimal swimming speed was generated by an impeller connected to an electric motor (model Kleedrive MS2 132 M-4 B3 (7.5 w), Brd. Klee A/S, Albertslund, Denmark). The motor was powered by an industrial inverter (IP66, model $\mathrm{n}^{0}$ BFI-E2-34-0180-3F4\#, Bejer Electronics, Malmo, Sweden) with an adjustable alternating current $(\mathrm{AC})$ from 0 to $50 \mathrm{~Hz}$. Inverter frequencies from 2.5 to $8.5 \mathrm{~Hz}$ were linked to flow speeds that were measured using a Vectrino acoustic Doppler velocimeter (ADV; NortekAS, Rud, Norway) in three dimensions (velocities $u, v$ and $w$ in directions $x, y$ and $z$ respectively) for $10 \mathrm{~s}$ with a sampling rate of $10 \mathrm{~Hz}$. Horizontal water velocity $(u)$ in the swim compartment increased proportionally to the AC-frequency of the inverter. Water parameters in the flume were kept the same as in the $800 \mathrm{~L}$ stocking tanks during the whole 10-week experiment.

\section{Determination of the optimal swimming speed in swim tunnels}

Fish were induced to swim at their optimal swimming speed $\left(\mathrm{U}_{\mathrm{opt}}\right)$. Over the course of the experiment $\mathrm{U}_{\mathrm{opt}}$ was determined three times to adjust the applied flow velocity in the flume: at weeks 1,5 and 9. For this purpose, two $127 \mathrm{~L}$ Blazka-type swim tunnels were used (described in detail by Van den Thillart et al. [23]). The day before the swim tunnel experiment, one seabass was introduced in each of the tunnels for overnight acclimatisation at the same light regime and water conditions as described before. Water velocity overnight was kept at $0.1 \mathrm{~m} \mathrm{~s}^{-1}$ to ensure sufficient water quality. The following morning, a critical swimming speed $\left(\mathrm{U}_{\text {crit }}\right)$ test was executed by starting at a swimming speed of $0.1 \mathrm{~m} \mathrm{~s}^{-1}$ and then increasing the swimming speed by $0.1 \mathrm{~m} \mathrm{~s}^{-1}$ every $10 \mathrm{~min}$ until the maximum swimming speed of $1 \mathrm{~m} \mathrm{~s}^{-1}$ was reached. All experimental fish were able to swim the full range of speeds and the $\mathrm{U}_{\text {crit }}$ test was finished after swimming $10 \mathrm{~min}$ at $1 \mathrm{~m} \mathrm{~s}^{-1}$, so $U_{\text {crit }}$ values were all $>1 \mathrm{~m} \mathrm{~s}^{-1}$. After the $U_{\text {crit }}$ test, fish were left recovering at the minimum speed $\left(0.1 \mathrm{~m} \mathrm{~s}^{-1}\right)$ for $120 \mathrm{~min}$. Subsequently, an $\mathrm{U}_{\mathrm{opt}}$ test was performed and oxygen $\left(\mathrm{O}_{2}\right)$ content was measured using for each tunnel a bypass with a galvanic oxygen electrode, both applied in a 4channel respirometry system (DAQ-PAC-G4; Loligo Systems Aps, Tjele, Denmark; Palstra et al., [22]). The decrease in $\mathrm{O}_{2}$ content which equals $\mathrm{O}_{2}$ consumption was measured at 4 different swimming speeds: 0.25, 0.50, 0.75 and $1 \mathrm{~m} \mathrm{~s}^{-1}$ in random order. Fish swam for $45 \mathrm{~min}$ at each speed after which they recovered at minimal speed for $15 \mathrm{~min}$. The tunnels recirculated water during the 45 min swimming periods to allow $\mathrm{O}_{2}$ measurements after which they were flushed during recovery. $\mathrm{O}_{2}$ data from minutes 15 to 45 at each speed were used for analyses. This protocol was repeated until $\mathrm{O}_{2}$ was measured for all four swimming speeds. Background $\mathrm{O}_{2}$ consumption with only water and no fish inside the tunnels was determined for data correction when found significant.

The percentual decline of oxygen content was used to directly calculate the cost of transport (COT) according to the formula:

$$
C O T=\frac{\Delta s a t_{(t)} \cdot m g_{\mathrm{O}_{2}}}{m \cdot \Delta d}
$$

where: $\Delta s a t_{(t)}$ is the \% decline in oxygen saturation during the measurement interval, $m g_{\mathrm{O}_{2}}$ is the amount of oxygen in $\mathrm{mg}$ per \% saturation under the given conditions, $m$ is the body mass of the fish in $\mathrm{kg}$ and $\Delta d$ is the covered distance in $\mathrm{m}$. COT data at $100 \% \mathrm{U}_{\text {crit }}$ were not considered when plotting the polynomial trend line due to the considerable anaerobic contribution to swimming at critical speeds. By equaling the first derivative of the polynomial function that described the relation between COT and the swimming speed $U(0.25,0.50$ and $0.75 \mathrm{~m} \mathrm{~s}^{-1}$ ) to zero, the $U_{\mathrm{opt}}$ was calculated (also Palstra et al. [24]). The solid blocking effect (SBE; [25]) was negligible. After each series of swim tunnel experiments, the newly determined $U_{\text {opt }}$ was adopted in the swim flume.

After each swim tunnel experiment, experimental fish were anesthetized (Clove oil, diluted 1:10 in absolute ethanol and then used at $2 \mathrm{ml} \mathrm{l}^{-1}$ water) and $1 \mathrm{ml}$ of blood was extracted from the caudal vein using heparin-flushed 
(10.000 IU ml $\mathrm{ml}^{-1}$ ) $1 \mathrm{ml}$ syringes that were immediately placed on ice after use. Hematocrit (Hct) values were measured in $9 \mu \mathrm{l}$ whole blood samples as triplicates per fish using a microcentrifuge (Spincrit microhematocrit centrifuge, Indianapolis, US). Fish were then euthanized by a blow on the head and measured for standard length (SL) and BW.

\section{Sample collection}

A subsample of fish $(N=15)$ was sampled at the start of the swim-experiment and subsamples of the exercised fish $(N=15)$ and the non-exercised controls $(N=15)$ were sampled every 2 weeks. At each sampling time, fish were anaesthetised, euthanized by decapitation and measured for SL and BW. Gonads were dissected and weighed to the nearest $0.01 \mathrm{~g}$ as gonad weight (GW). The gonadosomatic index (GSI) was then calculated as $\left(\mathrm{GW} \mathrm{BW}{ }^{-1}\right) * 100 \%$. Only at week $10,1 \mathrm{ml}$ of blood was extracted as described above, centrifuged at $4{ }^{\circ} \mathrm{C}(5 \mathrm{~min}$ at $9.500 \mathrm{x} \mathrm{g}$ ) and plasma was stored at $-80{ }^{\circ} \mathrm{C}$ for subsequent analysis of steroid levels. One of the two gonads from fish in week 10 was stored in RNAlater (Ambion) at $-20{ }^{\circ} \mathrm{C}$. The remaining gonad was stored in formalin ( $4 \%$ buffered formaldehyde) and kept at $4{ }^{\circ} \mathrm{C}$ for histological analyses. All samples were sent to the University of Barcelona for analyses.

\section{Plasma 11- ketotestosterone}

To quantify the levels of 11-ketotestosterone (11-KT) in plasma samples from males sampled in week 10, a commercial kit (11-keto Testosterone EIA Kit, Cayman Chemical Company, USA) was used following the manufacturer's specifications.

\section{Gonad histology}

The gonad samples in formalin were washed for $24 \mathrm{~h}$ in PBS, dehydrated in an ascending series of ethanol concentrations and then cleared in xylene and embedded in paraffin (pfm medical ag, Köln, Germany) for $1 \mathrm{~h}$ at $50{ }^{\circ} \mathrm{C}$. Subsequently, $6 \mu \mathrm{m}$ thick sections were cut using a microtome (model Leica 2235, Leica biosystems inc, Ontario, Canada), were mounted on polylysine slides, dried overnight at $37{ }^{\circ} \mathrm{C}$, and stored at $4{ }^{\circ} \mathrm{C}$. Sections were stained with hematoxylin-eosin, according to standard histological procedures [26, 27], and mounted using DPX medium (Scharlab, Barcelona, Spain). The sections were analysed under a bright field microscope (Olympus CX23, Olympus Deutschland $\mathrm{GmbH}$, Hamburg, Germany) to determine the sex and maturity stage of the gonads. Pictures of the histological sections were taken using a 12.5 Px DP70 digital camera (Olympus Deutschland GmbH, Hamburg, Germany). Phenotypic sex of these sections could be determined by microscopic examination [28]. Testicular samples were selected for further analyses. Stages of spermatogenesis were classified according to Begtashi et al. [11]. Germ cells were classified according to their topography, morphology, size and nuclear characteristics. Subsequently, the testis area covered by a particular cell type was calculated as percentage of the whole gonadal area in six individual males per group using the Image Plugin Analyze (ImageJ software (Rasband, W.S., Image), U.S. National Institutes of Health, Bethesda, Maryland, USA, http://imagej.nih.gov/ij/, 1997-2016). Gonadal area fractions were estimated by placing a 48 point grid on the image (microphotography) and then characteristic cell types were marked and counted trough the "cell counter" ImageJ tool according to Butts et al. [29]. The lumen's portion and the area that was not covering any tissue were excluded from the analysis.

\section{CDNA synthesis and quantitative Real Time PCR}

Testicular samples of exercised $(N=10)$ or nonexercised $(N=8)$ juvenile seabass at week 10, preserved in RNAlater, were processed for RNA purification, and cDNA synthesis and quantitative real time PCR (qPCR) were performed as previously described [30-32]. Briefly, total RNA was extracted with TRI Reagent Solution (Applied Biosystems) following the manufacturer's instructions and treated with DNaseI (amplification grade, 1 unit/ $\mu$ g RNA; Invitrogen). SuperScript III RNase HReverse Transcriptase (Invitrogen) was used to synthesise first strand cDNAs with oligo (dT)15 Primer (Promega) from $1 \mu \mathrm{g}$ of total RNA at $50{ }^{\circ} \mathrm{C}$ for $60 \mathrm{~min}$. Candidate genes involved in testicular development and function (Table 1) were selected from the GenBank nucleotide database and from the expressed sequence tags (ESTs) deposited in the Aquasea database (Aquagenomics Consortium; available to J. Planas).

Genes were selected according to their role in the three main processes of interest: testicular steroidogenesis, sertoli cell's function / spermatogonial proliferation, and progression of gonadal maturation. The markers involved in testicular steroidogenesis were represented by 3-beta-hydroxysteroid dehydrogenase (3ßhsd), 11-beta hydroxysteroid dehydrogenase (11ßhsd), indispensable for the production of $11-\mathrm{KT}$ and, by androgen receptoralpha (ara) and estrogen receptor-beta (er $\beta 2)$. The genes involved in sertoli cell's function and spermatogonial proliferation that were chosen were gonado-somal derived factor 1 (gsdf1) [33] and bone morpho-genetic protein (bmp15), proposed as a sperm quality regulator and with expression restricted to germ cells [34]. In the same group are also follicle stimulating hormone (fshr), the Fsh cognate receptor, the anti müllerian hormone (amh), and the insuline-like growth factor 1 (igf1) that besides its role as mediator of growth hormone in vertebrates also stimulates DNA synthesis in spermatogonia and is necessary for the continuation of spermatogenesis [35]. 


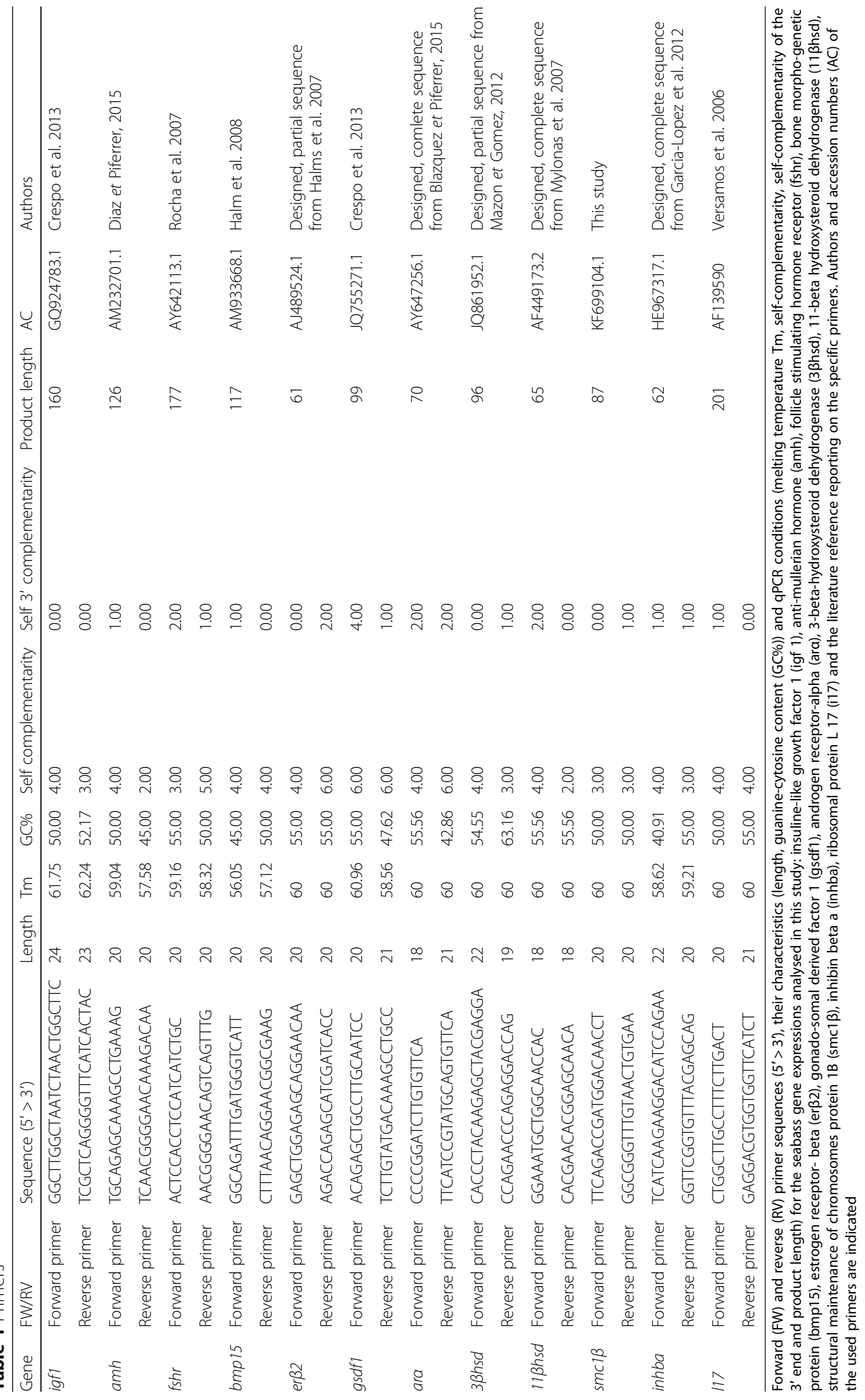


Finally, the genes involved in the progression of gonadal maturation that were chosen were structural maintenance of chromosomes protein $1 b(\operatorname{smc} 1 \beta)$, a gene required for the maintenance of meiotic cohesion [36], and inhibin beta a (inhba) a gene that participates in the regulation of Fsh synthesis and cell proliferation and differentiation [37, 38].

In order to isolate partial cDNAs encoding seabass 3-beta-hydroxysteroid dehydrogenase ( $3 \beta h s d)$, 11-betahydroxysteroid dehydrogenase (11ßhsd), anti müllerian hormone $(a m h)$, follicle stimulating hormone $(f s h r)$, androgen receptor isoform a (ar), the gonadosomal derived factor ( $g s d f 1)$, estrogen receptor isoform B (er $\beta 2)$, structural maintenance of chromosomes protein $1 \mathrm{~b}(\operatorname{smc} 1 \beta)$, bone morphogenetic protein 15 (bmp15) and insulin-like growth factor 1 (igf1), oligonucleotide primers were designed. Primer design for the selected candidate was done using the Roche Universal Probe Assay Library except for those for which primer sequence was already published: fshr [39], amh [40], gsdf1 [32] and L17 (l17) [41] smc1ß primers were designed using the conserved region of the partial Solea senegalensis mRNA sequence available in GenBank. Each qPCR was run in triplicate in 96-well plates using a MyiQ Real Time PCR Detection System (Bio-Rad Laboratories, Inc., Hercules, California, USA). The qPCR amplification reaction mixture, with a final volume of $10 \mu \mathrm{l}$, contained $2 \mu \mathrm{l}$ of cDNA diluted 1:10 to $1: 100$ depending on the transcript. Specifically, a cDNA dilution of 1:100 was used for gsdf1 and $\operatorname{smc1\beta }$; for all other qPCR reactions cDNA had a dilution of 1:10. Relative gene expression to the reference gene $l 17$ was determined using the iQ5 Optical System software 2.1 (Bio-Rad). Ten-fold dilution series, from the most to the least concentrated cDNA samples, were used to test primer efficiencies. Primer efficiencies ranged from 95.6 to $103.0 \%$ and excluded the presence of relevant sub-optimal annealing temperatures; poorly designed primers; the formation of amplicons with secondary structures; and occurrence of primer-dimers, that may have affected our results. To determine the precision of the qPCR assay, intra-assay (repeatability) and the inter-assay (reproducibility) fidelity levels, average CT values and SDs were used and reported as coefficients of variation (CVs, $\mathrm{SD} /$ mean $\times 100 \%)$. Coefficient of variations $(\mathrm{CV} \%)$ of triplicates was checked to be smaller than 1. When CV\% was found to be higher than 1, duplicate measurements were used if possible. When also the use of duplicates was not appropriate, the entire data point was omitted from the analysis. $\mathrm{CV} \%$ values were also calculated in all the replicates from the two groups, both intra and inter assays. Reference gene $l 17 \mathrm{CV} \%$ was $0.78 \%$, for all the other genes analysed $\mathrm{CV} \%$ values ranged from 0.85 to $3.12 \%$. Inter assays variability showed a CV\% value of $2.19 \%$. Primer sequences, characteristics and qPCR conditions and product length for the seabass genes analyzed in this study are shown in Table 1.

\section{Statistical analyses}

After collecting the data, statistical analysis was performed to search for differences between the dependent factors of individuals from both groups (RESTERS and SWIMMERS). All the data obtained, except for gene expression and GSI, were analyzed with the software SPSS Statistics 17.0 (SPSS Inc. Released 2008. SPSS Statistics for Windows, Version 17.0. Chicago, USA). BW, SL and 11-KT values were normally distributed (D'Agostino Pearson omnibus normality test). For 11-KT values, significant differences between the treatments were determined by performing a t-test. For BW and SL, two-way ANOVA was performed according to the model: Week (repeated factor); Treatment (Rest vs Swim); Week $\mathrm{x}$ Treatment interaction, and Residual error. The GSI values were not normally distributed and were instead compared among treatments with a Mann Whitney U test followed by a Benjamini-Hochberg procedure for false discovery rate correction to exclude type I errors. Using three replicates per sample, relative gene expression values $\left(\Delta C_{T}\right)$ were obtained using the iQ5 Optical System software 2.1 (Bio-Rad Laboratories, Inc., Hercules, California, USA) as indicated in the calculation spreadsheet provided by the manufacturer and derived from the algorithms outlined by Vandesompele et al., [42]. Expression values were then normalized to the control group by dividing the individual gene expression values from both groups by the average expression value of the control group. Statistically significant differences $(P<0.05)$ were determined by performing a MannWhitney test using the GraphPad Prism Software for windows version 6.0. (GraphPad Software, La Jolla California USA).

\section{Results}

Determination of optimal swimming speeds throughout the swimming training experiment

Fish at week 1 weighed $19 \pm 1 \mathrm{~g}$, measured $10.2 \pm 0.2 \mathrm{~cm}$ in SL and had a Hct level of $46 \pm 2 \%$. The formula of the COT polynomial trend line was determined as $y=6$. $9002 x^{2}-9.1459 x+3.67$. $U_{\text {opt }}$ of fish at week 1 was then calculated at $0.66 \mathrm{~m} \mathrm{~s}^{-1}$ at a minimal cost of transport $\left(\mathrm{COT}_{\min }\right)$ of $0.64 \mathrm{mg} \mathrm{kg}^{-1} \mathrm{~m}^{-1}$. Fish at week 5 weighed $38 \pm 3 \mathrm{~g}$, measured $12.7 \pm 0.3 \mathrm{~cm}$ in SL and had a Hct level of $41 \pm 1 \%$. The formula of the COT polynomial trend line was determined as $2.9018 \mathrm{x}^{2}-4.0186 \mathrm{x}+1.7867$. $\mathrm{U}_{\text {opt }}$ of fish at week 5 was then calculated at $0.69 \mathrm{~m} \mathrm{~s}^{-1}$ at a $\mathrm{COT}_{\text {min }}$ of $0.40 \mathrm{mg} \mathrm{kg}^{-1} \mathrm{~m}^{-1}$. Finally, fish at week 9 weighed $77 \pm 7 \mathrm{~g}$, measured $15.7 \pm 0.5 \mathrm{~cm}$ in SL and had a Hct level of $43 \pm 1 \%$. The formula of the COT polynomial trend line was determined as $2.0028 x^{2}-2.7487 x+1.1353$. $\mathrm{U}_{\text {opt }}$ of fish at week 9 was then calculated at $0.69 \mathrm{~m} \mathrm{~s}^{-1}$ at a $\mathrm{COT}_{\text {min }}$ of $0.19 \mathrm{mg} \mathrm{kg}^{-1} \mathrm{~m}^{-1}$. Thus, although the weight and the length increased and the $\mathrm{COT}_{\min }$ decreased during 
the swimming training period, the $\mathrm{U}_{\mathrm{opt}}$ hardly changed, increasing only from 0.66 to $0.69 \mathrm{~m} \mathrm{~s}^{-1}$. Therefore, a similar $U_{\text {opt }}$ was applied throughout the course of the experiment in the swim flume.

\section{Effects of swimming training on size and GSI in juvenile seabass}

The results of BW, BL and GSI, analyzed for fish at weeks 2, 4, 6, 8 and 10 are shown in Figs. 1, 2 and 3 respectively. BW and SL increased gradually over time throughout the experiment $(P<0.0001$; Figs. 1 and 2$)$. Only SL showed a significant difference between swimmers and resters $(P=0.004)$ with swimmers being slightly shorter. Gonad weight was lower than $0.01 \mathrm{~g}$ for all fish during the first 6 weeks of the experiment and, consequently, GSI values were almost 0 for weeks 2 , 4 and 6. GSI increased at weeks 8 and 10 with swimmers showing lower GSI values than resters, although differences between the two groups were not statistically significant (Fig. 3). At week 10, male and female gonads could be discriminated macroscopically and, consequently, the males could be identified to determine the swimming-induced effects on testicular development. The sex ratio at week 10 was $58 \%$ males and $42 \%$ females. Table 2 provides the results for only the males of the swimming and resting groups at week 10. No statistically significant differences in weight nor in length between the male swimming and resting groups were detected, although male swimmers tended to be smaller than male resters. In addition, no differences in Fulton's condition factor (K; Fulton, [43]) were observed between male swimmers and resters (Table 2). Importantly, at week 10 the GSI values from the male swimmers were significantly lower than the male resting controls.

\section{Effects of swimming training on 11-KT plasma levels in male juvenile seabass}

Plasma samples from male seabass sampled at week 10 were used to determine the levels of 11-KT in resting

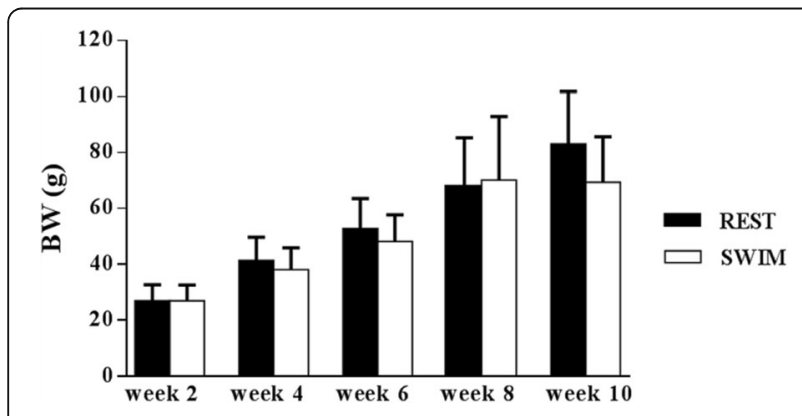

Fig. 1 Time-related effects of swimming training on body weight (BW) in juvenile seabass. Resters (REST; $N=15$ ) and swimmers (SWIM; $N=15$ ) which swam at $U_{\text {opt }}$ during a 10 -week period in the swim flume. A significant time effect existed $(P<0.0001)$ but no treatment effects

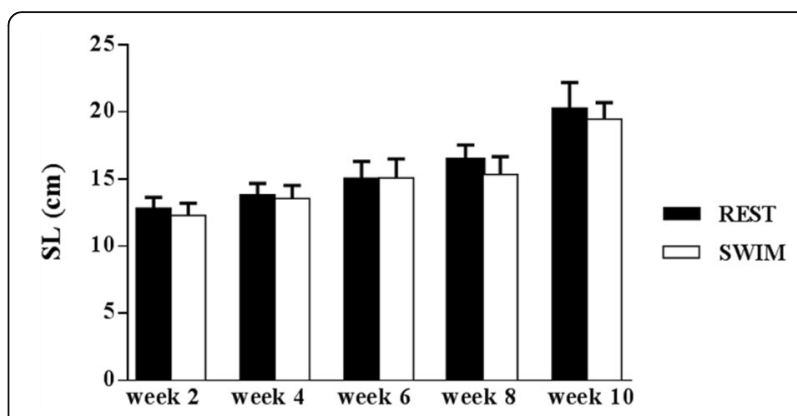

Fig. 2 Time-related effects of swimming training on standard length (SL) in juvenile seabass. Resters (REST; $N=15$ ) and swimmers (SWIM; $N=15$ ) which swam at $U_{\text {opt }}$ during a 10-week period in the swim flume. A significant time effect $(P<0.0001)$ and treatment effects existed $(P=0.004)$

$(N=9)$ and swimming $(N=7)$ males. Our results show that plasma 11-KT levels were similar and not significantly different between swimmers and resters (Fig. 4).

Effects of swimming training on testicular development in male juvenile seabass

Stages of spermatogenesis of testes from males sampled at week 10 were determined and classified as stage I-II (immature and early recrudescence, respectively) and stage III (mid recrudescence) according to Begtashi et al. [11]. A high predominance of easily recognizable cysts, late spermatogonia A ( $\operatorname{lsgA})$ and a small fraction of primary spermatocytes (sc1) were found in the testes of resting control males as opposed to the testes of swimmers, in which no sc1 and disperse lsgA were identified but that contained a clear predominance of spermatogonia (sgA) (Fig. 5). In the resting males, the percentage of covered gonadal area represented by lsgA was 37\% higher than in the swimming males. The characteristic histological condition found in testes from swimmers corresponded to the earlier phases of spermatogenesis (stage I and II) as shown in seabass by Rodriguez et al. [15]. Resting males showed a testicular structure generally consisting in relatively well formed cysts containing SgA, lsgA and disperse sc1 (Fig. 5a). In contrast, the testicular structure of most swimmers consisted of less and smaller cysts, with a predominance of sgA and disperse lsgA (Fig. 5b).

Effects of swimming training on the expression of genes involved in testicular development and function

In view of the observed changes in testicular development in juvenile seabass males subjected to sustained swimming, we proceeded to study the molecular basis of these changes by measuring the mRNA expression levels of genes known to participate in spermatogenesis in seabass. The majority of the analyzed genes involved in testicular development and function showed a significant 


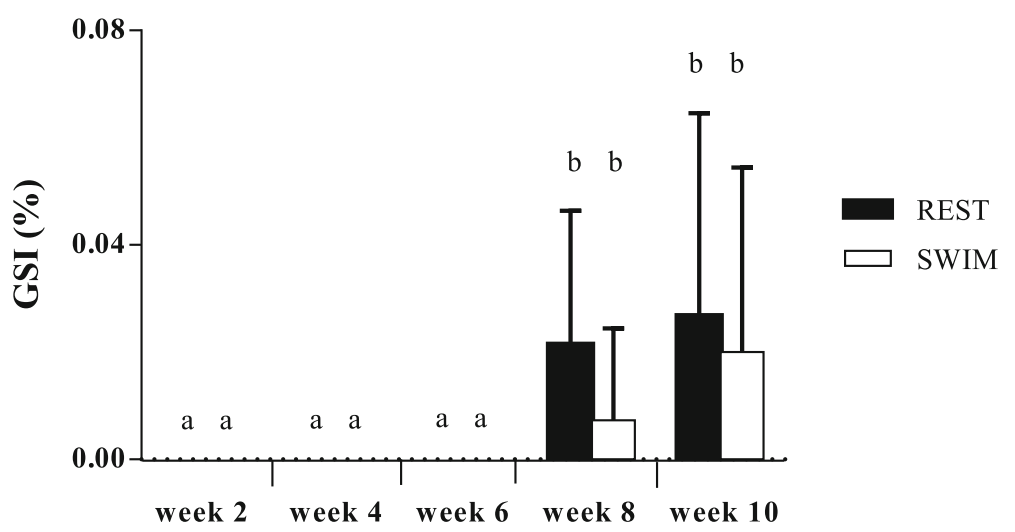

Fig. 3 Time-related effects of swimming training on gonadosomatic index (GSI) in juvenile seabass. Resters (REST; $N=15)$ and swimmers (SWIM; $N=16$ ) which swam at $U_{\text {opt }}$ during a 10-week period in the swim flume. Bars that do not share a letter are statistically different $(P<0.05)$ and represent the mean \pm SD of males and females combined

down-regulation in their mRNA expression levels in testes from swimmers when compared to resters at week 10. Specifically, the mRNA expression of genes involved in testicular steroidogenesis was down-regulated in swimming males when compared to resting males. Expression of $3 \beta h s d$, involved in progesterone synthesis, and $11 \beta h s d$, indispensable for the production of $11-\mathrm{KT}$, was down regulated in swimming males $(P=0.0085$ and $P<0.0001$, respectively) (Fig. 6). Similarly, testicular expression of $\operatorname{er} \beta 2(P=0.0002)$ was significantly downregulated in swimming males as compared to resting ones (Fig. 6). The androgen receptor $\alpha$ (ara) was the only one among the steroidogenic functional markers that did not show significant down-regulation in response to swimming, although a trend towards lower mRNA expression values was detected in swimmers (Fig. 6).

The analyzed genes involved in testicular germ cells development and differentiation showed a similar down regulation trend as observed for the steroidogenic markers. The mRNA expression of the Fsh cognate receptor $f s h r$ and the Anti-Müllerian hormone amh was significantly down regulated in swimmers $(P=0.0117$ and $P=0.0205$, respectively) (Fig. 7). Furthermore, $g s d f 1$,

Table 2 Biometric measurements

\begin{tabular}{lll}
\hline & RESTERS & SWIMMERS \\
\hline $\mathrm{N}$ & 9 & 10 \\
$\mathrm{BW}(\mathrm{g})$ & $83 \pm 19$ & $69 \pm 16$ \\
$\mathrm{SL}(\mathrm{cm})$ & $16.5 \pm 1.11$ & $15.4 \pm 1.33$ \\
$\mathrm{GW}(\mathrm{g})$ & $0.038 \pm 0.028$ & $0.031 \pm 0.021$ \\
$\mathrm{GSI}(\%)$ & $0.003 \pm 0.003$ & $0.000 \pm 0.000^{*}$ \\
$\mathrm{Hct}$ & $48 \pm 5$ & $48 \pm 5$ \\
K & $0.018 \pm 0.000$ & $0.018 \pm 0.000$
\end{tabular}

Body weight (BW), standard length (SL), gonad weight (GW), gonado-somatic index (GSI), haematocrit (Hct), and Fulton's condition factor (K) values from resting (RESTERS, $N=9$ ) and swimming (SWIMMERS, $N=10$ ) males at the last dissection (week 10). Values are averages \pm SD. ${ }^{*}=P<0.05$ a gene involved in spermatogonial proliferation [33], showed a strong down-regulation $(P<0.0001)$ in swimmers vs. resters (Fig. 7). In swimmers, the mRNA expression levels of $b m p 15$, proposed as a sperm quality regulator and whose expression is restricted to germ cells [34], were lower than in resters, even though not significantly (Fig. 7). The only gene that showed upregulated mRNA expression levels in swimmers over resters, although not significantly, was igfl, that beside its role as mediator of growth hormone in vertebrates, stimulates DNA synthesis in spermatogonia and is necessary for the continuation of spermatogenesis [35] (Fig. 7).

The expression of genes necessary for the progression of gonadal maturation was down regulated in swimmers. Expression of $s m c 1 \beta$, a gene required for the maintenance of meiotic cohesion [36], and inhba, a gene that participates in the regulation of Fsh synthesis and cell proliferation and differentiation [37, 38], was downregulated in swimming males as compared to resting males ( $P=0.0234$ and $P=0.0002$, respectively; Fig. 8$)$.

\section{Discussion}

This is the first study that evaluates the effects of swimming-induced exercise on testicular development in seabass with the aim to reduce the incidence of precocious sexual maturation during farming conditions. Moreover, this study provides insights into the regulatory mechanism of early testicular development on molecular level which is clearly suppressed by swimminginduced exercise, suggesting that forced swimming exercise, during the onset of testicular development, could therefore be used as a natural and non-invasive treatment to inhibit testicular development.

In seabass, early puberty is sensitive to photoperiod manipulation until approximately 200 days after hatching and, consequently, this period has been considered to be the critical time in which the onset of gametogenesis may 


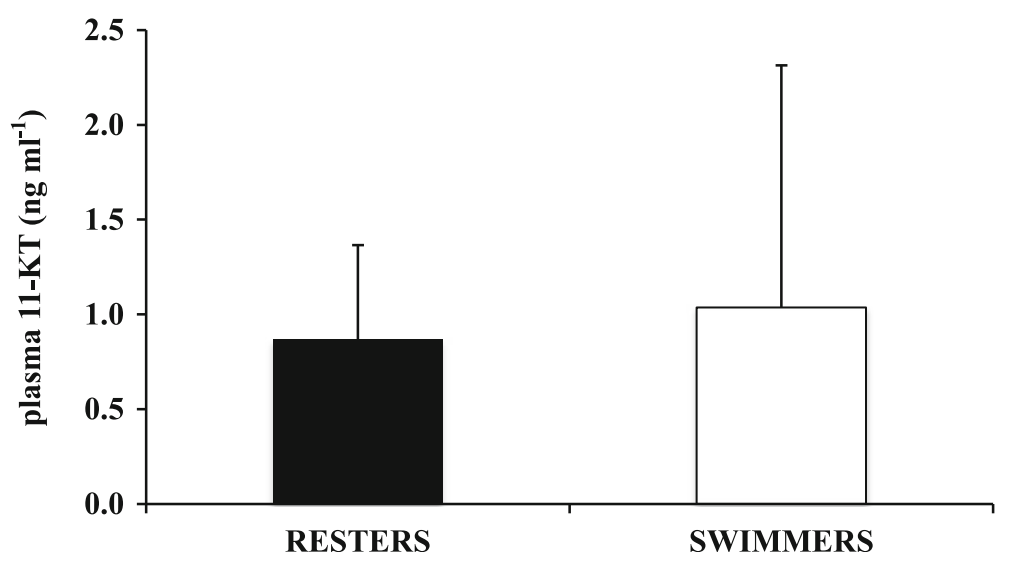

Fig. 4 Effects of swimming training on plasma 11-ketotestosterone (11-KT) levels in juvenile male seabass at week 10. Resters $(N=9)$ and swimmers $(N=7)$ which swam at $U_{\text {opt }}$ during a 10-week period in the swim flume. Bars represent the mean \pm SD
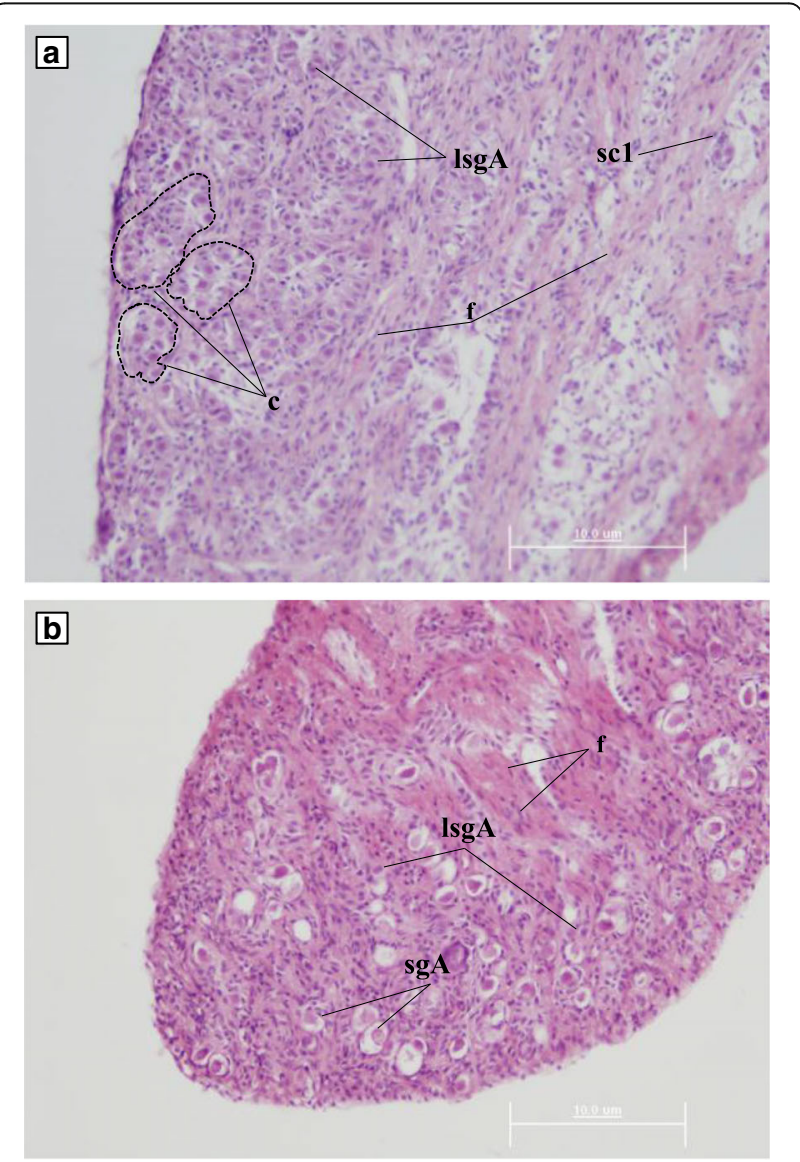

Fig. 5 Histological analysis of testicular samples from resters (a) and swimmers (b). Spermatogonia A (sgA), late spermatogonia A (IsgA), primary spermatocytes (sc1) and fibrocytes (f) are indicated by solid arrows. Spermatic cyst (c) are delineated by dashed lines. Representative images are shown take place [16]. During this window of time, we hypothesized that swimming-induced exercise may also have a modulatory effect on precocious maturation by inhibiting the gonadotropic production that initiates the gonadal maturation phenomenon. Our results confirm that the selected age and size class of the fish used in this experiment are subject to puberty manipulation as previously observed by other authors [16]. Clearly, further studies are needed to determine whether swimming-induced exercise can have permanent effects on testicular development and whether this approach may represent a potentially cost-effective manipulation of gonadal development in seabass males.

Swimming-induced exercise in our study consisted of 10 weeks of continuous swimming at the optimal swimming speed. Throughout this period, optimal swimming speeds evolved from $0.66 \mathrm{~m} \mathrm{~s}^{-1}$ to $0.69 \mathrm{~m} \mathrm{~s}^{-1}$ for juvenile seabass with an initial BW and SL of $19 \pm 1 \mathrm{~g}$ and $10.2 \pm 0.2 \mathrm{~cm}$, respectively, and with a final BW and SL of $77 \pm 7 \mathrm{~g}$ and $15.7 \pm 0.5 \mathrm{~cm}$, respectively, in seawater at $25{ }^{\circ} \mathrm{C}$. These $\mathrm{U}_{\text {opt }}$ values are higher than the $\mathrm{U}_{\text {opt }}$ of $0.58 \mathrm{~m} \mathrm{~s}^{-1}$ as reported by Claireaux et al. [44] for larger seabass (range of 105-248 g BW) swimming in seawater at $26{ }^{\circ} \mathrm{C}$. The effects of swimming-induced exercise are mainly dependent on the applied speed. The stimulating effects of swimming exercise on growth and disease resistance display a clear optimum at a specific speed [45] which is similar to the optimal metabolic swimming speed as determined by respirometry [46]. Therefore we chose $U_{\text {opt }}$ as the swimming speed for our study, but it should be considered that speeds lower or higher than $U_{\text {opt }}$ will most probably lead to a difference in results. Our results suggest that swimming at optimal swimming speeds for 10 weeks resulted in a suppressive effect on testicular development in this species.

As hypothesized, swimming activity applied during the beginning of spermatogenesis may have inhibited 

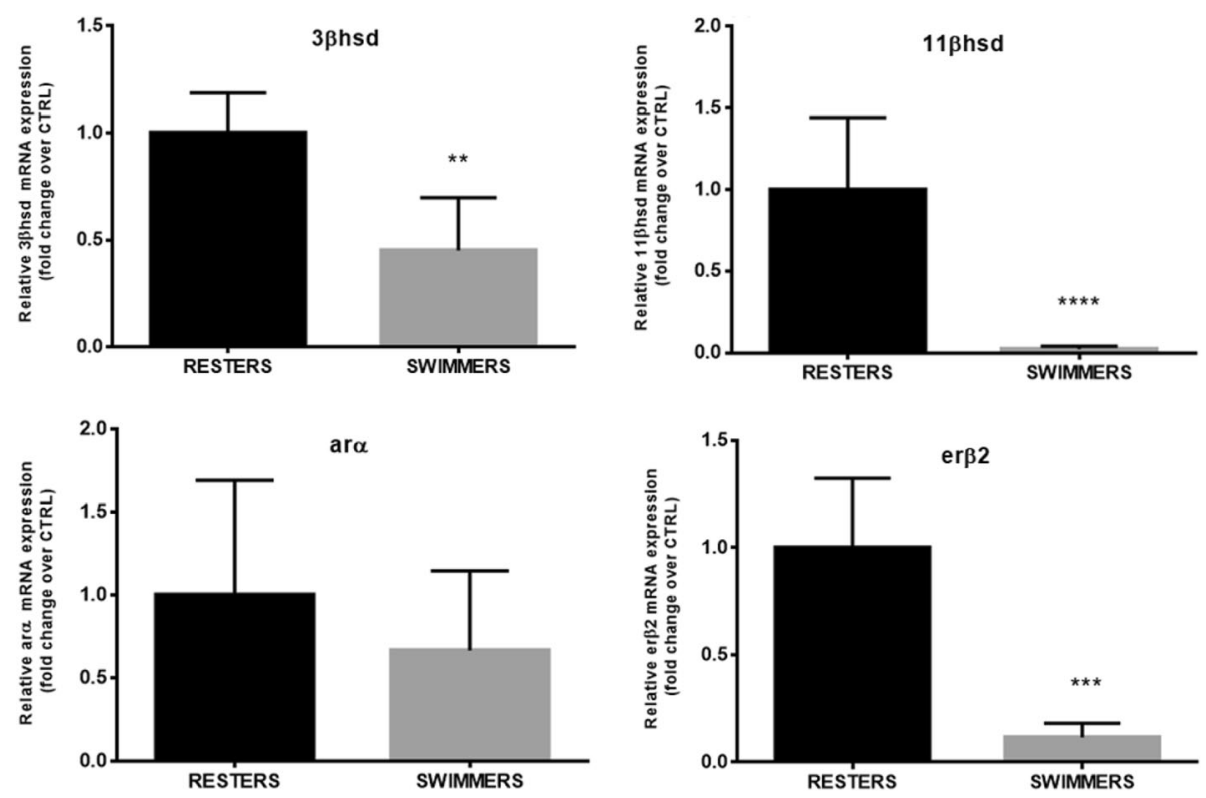

Fig. 6 Expression of genes involved in testicular steroidogenesis: 3-beta-hydroxysteroid dehydrogenase (3ßhsd), 11-beta hydroxysteroid dehydrogenase $(11 \beta h s d)$, androgen receptor-alpha (ara) and estrogen receptor-beta (er $\beta 2)$ in juvenile seabass males subjected to swimming at $U_{\text {opt }}$ (SWIMMERS) or not (RESTERS) for 10 weeks. Data are shown as mean \pm SD. Asteriks indicate statistical differences $\left({ }^{*} P<0.05 ;{ }^{* *} P<0.01 ;{ }^{* * *} P<0.001 ;{ }^{* * *} P<0.0001\right)$

testicular development as a result of increased energy expenditure. The performed histological analysis showed a high predominance of larger and easily recognizable cysts, late spermatogonia A and a small fraction of primary spermatocytes in the non-exercised control fish as opposed to the swimmers in which no primary spermatocytes and late spermatogonia A were detected. This particular histological condition found in swimmers corresponds to an earlier stage of spermatogenesis (I-II) than that found in the non-exercised control fish (III) [16], reminiscent of the delayed testicular development observed in male seabass subjected to long-term exposure to a continuous light photoperiod (Begtashi et al. [11]), and is in accordance with the lower GSI values observed in swimmers. Supporting these findings, the mRNA expression levels of $f s h r$, the Fsh cognate receptor, were down-regulated (4-fold) in swimming fish. In the fish testis, $f s h r$ is predominantly expressed in Sertoli cells and its mRNA expression levels increase in male sea bass during gonadal growth, presumably due to the proliferation of Sertoli cells [47-49]. This receptor has been detected both in the germinal and in the somatic components of the gonads of several fish species such as Japanese eel (A. japonica), African catfish (C. gariepinus), zebrafish (D. rerio), and Senegalese sole (S. senegalensis) [50-53]. Fsh is widely considered an essential component in triggering the onset of gonadal maturation in fish $[54,55]$ and has a crucial role in initiating spermatogenesis by regulating several Sertoli cell functions (e.g., nutritional, structural, paracrine) through its receptor and by inducing the mRNA expression and activity of enzymes involved in the steroidogenic pathway during early spermatogenic stages $[48,53]$. Accordingly, the steroidogenic markers $3 \beta h s d$ and $11 \beta h s d$ selected in this study showed a decreased testicular expression in exercised seabass as compared to the non-exercised controls (50- and 2- fold, respectively), suggesting an impairment of enzymes that are indispensable for the production of gonadal steroids and, consequently, for the entire maturation process [55]. $3 \beta h s d$ is specifically involved in the conversion from pregnenolone to progesterone [56] and, a recent study in juvenile male flatfishes, co-localized its presence together with the isoform a of the Fsh receptor in the interstitial component of the testicle, suggesting an Fsh-mediated action that relies on Leydig cell-derived steroids during early testicular development [57]. On the other hand, 11ßhsd is involved in the conversion of testosterone into 11ketotestosterone (11-KT), a key hormone in the onset of puberty of male teleosts $[58,59]$, including seabass $[47,60]$. Rodríguez et al. determined plasma 11-KT levels during the first sexual maturation in pre-pubertal seabass (i.e. 1-yr old) exposed to expanded (18 months) and compressed (6 months) photoperiods and reported that 11-KT levels were lower under a modified photoperiod than under a natural photoperiod. It has recently been found that, at the onset of puberty in seabass, an increase in 11-KT levels is well correlated with a high incidence of precocious males [61]. However, we did not find any detectable differences in plasma 11-KT levels yet between swimming and resting seabass in this study, in contrast to the 

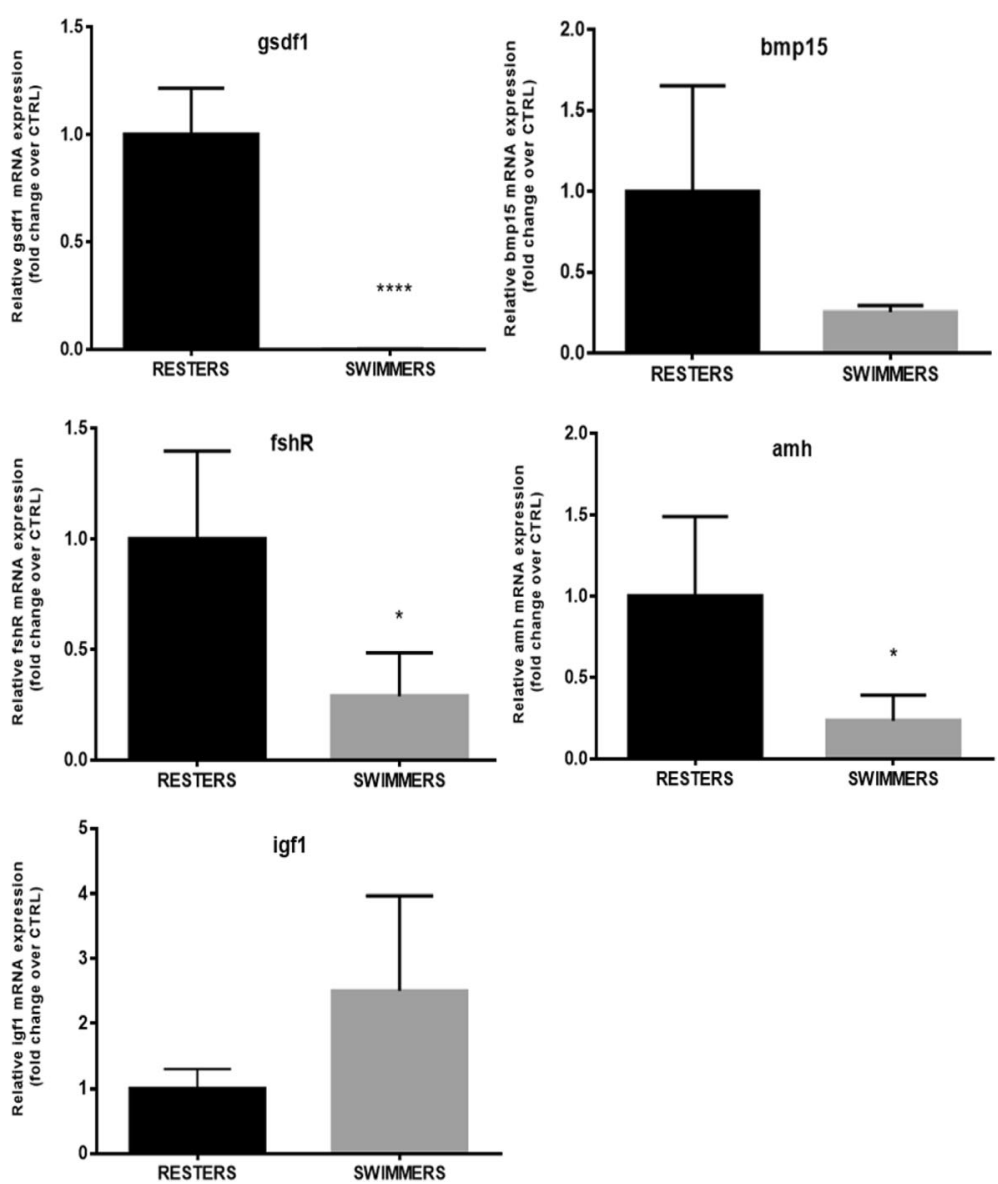

Fig. 7 Graphs showing the expression of genes involved in sertoli cells' function and spermatogonial proliferation: gonado-somal derived factor 1 (gsdf1), bone morpho-genetic protein (bmp15), follicle stimulating hormone (fshr), anti müllerian hormone (amh), and insuline-like growth factor 1 (igf1) in juvenile seabass males subjected to swimming at $\mathrm{U}_{\text {opt }}$ (SWIMMERS) or not (RESTERS) for 10 weeks. Data are shown as mean \pm SD. Asteriks indicate statistical differences $\left({ }^{*} P<0.05 ;{ }^{* *} P<0.01 ;{ }^{* * *} P<0.001\right.$; ${ }^{* * * *} P<0.0001$ )

observed differences in testicular gene expression and histological data. Similarly, we found no significant differences in androgen receptor $\alpha$ (ar $\alpha)$ mRNA expression levels as a consequence of swimming, thus indicating that androgen action may not be altered by swimming at this developmental stage. Moreover, recent studies have shown how Fsh, but not 11-KT, is able to stimulate spermatogonial proliferation [38] adding strength to our findings. In particular, these authors evidenced how Fsh action is likely influenced by steroids but that these are not able to fulfill all Fsh functions necessarily required to initiate spermatogenesis.
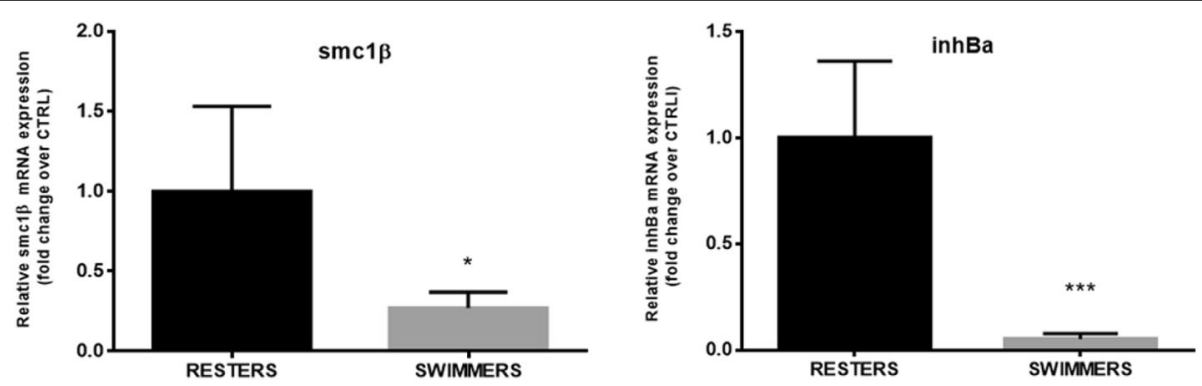

Fig. 8 Graphs showing the expression of genes necessary for the progression of gonadal maturation: structural maintenance of chromosomes protein $16(s m c 1 \beta)$ and inhibin beta a (inhba) in juvenile seabass males to swimming at $U_{\text {opt }}$ (SWIMMERS) or not (RESTERS) for 10 weeks. Data are shown as mean \pm SD. Asteriks indicate statistical differences $\left({ }^{*} P<0.05 ;{ }^{* *} P<0.01 ;{ }^{* *} P<0.001\right.$; ${ }^{* * *} P<0.0001$ ) 
Testicular expression of the estrogen receptor er $\beta 2$ was significantly down-regulated (9-fold) in swimming seabass, suggesting again that swimming could result in the inhibition of mitotic spermatogonial division, also supported by the lower number of lsgA observed in this group. These results agree with the notion that estrogens, in particular $E_{2}$ produced by the interstitial Leydig cells mainly under Fsh stimulation, have a pivotal role in regulating spermatogenesis in the early phases of spermatogonial proliferation through Sertoli cell intercession $[55,62]$. In the teleost testis, estrogen receptors have a direct control on the expression of the Anti-Müllerian hormone (amh) [63] and high expression levels of er $\beta 1$ and $\operatorname{er} \beta 2$ have been associated with early stages of precocious maturation in seabass males [64]. The observed lower mRNA expression levels of amh in swimmers vs. resters (5-fold), a factor known to induce spermatogonial stem-cell renewal and that is normally secreted together with inhba and igf 1 by Sertoli cells under Fsh-stimulated 11-KT production from Leydig cells [55], evidences a modulation of spermatogenesis that also affects the shift from mitotic to meiotic processes in the gonads of swimming fish.

In support of the hypothesis that not only the steroidogenic pathway but also factors involved in the regulation of spermatogonial proliferation may have been modulated by swimming, the expression of $\operatorname{smc} 1 \beta$, a gene whose product is required for the maintenance of meiotic cohesion, was down-regulated in swimmers and presumably related to the detected decrease in $f s h r$ mRNA expression levels. Chauvignè et al. [65], found a steroid-dependent positive regulation of $\operatorname{Smc} 1 \beta$ production by gonadotropins at the same testis developmental stage (I-II) as the seabass in our study. Since this gene is expressed in germ cells surrounding the Sertoli cells and it has been found essential for the recombination between homologues during meiotic prophase [36], we propose that in swimmers the progress of meiosis may have been inhibited. This finding is also supported by the lack of primary spermatocytes found in the testes of the swimming group and importantly by the strong down-regulation (630-fold) of the expression of gsdf1, another gene involved in spermatogonial proliferation under Fsh-induced $E_{2}$ release [55] and whose expression is restricted to Sertoli cells surrounding spermatogonia A [33, 65, 66]. Sawatari et al. [66] suggested a role for gsdf1 in the proliferation of spermatogonial stem cells or undifferentiated spermatogonia A. Moreover, the observed down-regulation of its expression in testes from swimmers strengthens the idea that this gene may be a target candidate for puberty manipulation, although more accurate studies on its function and involved pathways have to be performed. Also, it has been found that both $g s d f$ and amh, despite their demonstrated gonadotropic dependency [65], are under the control of progesterone [63] and we can speculate that their decreased expression in testis from swimmers may relate to the decreased expression levels of $3 b h s d$ observed in swimmers.

Finally, the expression of inhba, a member of the activin family that stimulates $\mathrm{SgA}$ proliferation since it encodes the active form of the dimeric protein activin A $[67,68]$, was down-regulated 20 -fold in swimmers as compared to the non-exercised controls. Rolland and collaborators [69] suggested that in O. mykiss, the inhibition of inhba during more advanced spermatogenetic stages (III to $\mathrm{V}$ ) would prevent the formation of a biologically active form of activin A, blocking germ cell proliferation and, consequently, permitting their meiotic differentiation. Conversely, our results suggest that in prepubertal seabass the down regulation of inhba expression by swimming is not by itself sufficient to trigger meiotic differentiation since $\operatorname{smc} 1 \beta$ expression was at the same time down-regulated and no primary spermatocytes were observed in swimmers. All the abovementioned molecular data on testicular markers are in accordance with the histological observations in suggesting that swimming activity may have delayed spermatogenesis.

Overall, swimming activity may have operated by modulating the switch from an immature and nonreceptive gonad to a hormonally competent one, thus affecting the BPG axis. One possible mechanism to try to explain the observed $f s h r$ down-regulation, and the subsequent pathways deriving from it leading to decreased testicular development, could be related to androgendependent dopaminergic regulation. Sex steroids have been shown to exert both negative and positive feedbacks on the gonadotropic/dopamine (DA) system through regulatory feedback [70]. The amplitude and the direction of this regulatory action is variable according to the development stage and the species analyzed [71-73]. As DA is also involved in the control of locomotion in fish [74, 75] and is able to inhibit the GnRH-induced pituitary gonadotropin production and, consequently, puberty [70], it may be hypothesized that this neurotransmitter may be at the base of the observed delay. Interestingly, previous studies have shown the tight relation between androgens and the dopaminergic system in another species [76] but to our knowledge no evidence is yet present for European seabass. It has to be mentioned that, currently, defining the role of DA in relation to early puberty and/or locomotor activity remains a challenging endeavour due to the complex physiological and adaptive roles that this signal can assume [54]. Another possible alternative or co-occurring mechanism underlying the observed reduction in testicular development by swimming could include a decline in the adiposity signal leptin due to reduced lipid levels caused by swimming as a high energy demanding activity. In European sea bass it has been shown that leptin has a 
positive effect on gonadotropin release [77]. However, there is no information on the possible regulation of leptin by swimming in teleosts. Obviously, further studies are required to clarify the roles of locomotor activity in determining the onset of puberty in teleosts.

\section{Conclusions}

In conclusion, our results indicate that juvenile seabass males which were subjected to swimming exercise at optimal swimming speeds for 10 weeks experienced delayed testicular development. The role of several factors involved in testis development in this species was discussed with particular emphasis to their relation with swimming activity. Importantly, the results from this study strongly suggest that forced swimming exercise, during the onset of testicular development, can therefore be used as a natural and non-invasive treatment to inhibit testicular development. This study shows the promise for swimming-induced exercise in reducing the incidence of sexually precocious males with the resulting improvement in productivity and cost reduction in seabass aquaculture.

\section{Abbreviations}

11-KT: 11-ketotestosterone; 11ßhsd: 11-beta hydroxysteroid dehydrogenase; 3ßhsd: 3-beta-hydroxysteroid dehydrogenase; ADV: Acoustic Doppler velocimeter; amh: Anti-mullerian hormone; BPG: Brain-pituitary-gonad; BW: Body weight; COT: Cost of transport; COT $\min$ : Minimal cost of transport; DA: Dopamine; erß2: Estrogen receptor-beta; ESTs: Expressed sequence tags; fshr: Follicle stimulating hormone receptor; gsdfi: Gonado-somal derived factor 1; GSI: Gonadosomatic index; GW: Gonad weight; Hct: Hematocrit; inhba: Inhibin beta A; K: Fulton's condition factor; IsgA: Late spermatogonia A; MBBR: Moving bed biofilm reactor; $\mathrm{O}_{2}$ : Oxygen; RAS: Recirculating Aquaculture System; sc1: Primary spermatocytes; sgA: Spermatogonia; SL: Standard length; smc1B: Structural maintenance of chromosomes protein $1 B ; U_{\text {crit: }}$ Critical swimming speed; $\cup_{\text {opt: }}$ Optimal swimming speed
\end{abstract}

\section{Acknowledgements}

The authors thank A. Hofman, H. Zeedijk and Y. van Es (Wageningen Marine Research, formerly IMARES) for animal care and maintenance, M. Durfort (University of Barcelona) for support with histology and G. van den Thillart for the swim tunnel collaboration.

\section{Funding}

Experiments were performed with the support of the AQUAEXCEL grant SWIMBASS (No. 0096/06/15/32) and an Erasmus Practicum grant to R. Benito. Gene expression and testis histology studies were performed during a Short-Term Scientific Mission of M. Graziano supported by the COST Action FA1304 "Swimming of fish and implications for migration and aquaculture (FITFISH)."

\section{Availability of data and materials}

The datasets used and/or analysed during the current study are available from the corresponding author on reasonable request.

\section{Authors' contributions}

Conceived and designed the experiments: JVP and APP. Performed the experiments: RB and APP. Performed lab analyses: RB and MG. Analyzed the data: MG, RB, JVP and APP. Wrote the paper: MG, RB, JVP and APP. All authors read and approved the final manuscript.

\section{Ethics approval}

Experimental protocols complied with the current laws of the Netherlands and were approved by the animal experimental committee (DEC nr. 2014038).

\section{Competing interests}

The authors declare that they have no competing interests.

\section{Publisher's Note}

Springer Nature remains neutral with regard to jurisdictional claims in published maps and institutional affiliations.

\section{Author details}

'Department of Physiology and Immunology, School of Biology, University of Barcelona, Diagonal 643, 08028 Barcelona, Spain. ${ }^{2}$ Wageningen Marine Research, Wageningen University \& Research, Korringaweg 5, 4401, NT, Yerseke, The Netherlands. ${ }^{3}$ Wageningen Livestock Research, Wageningen University \& Research Animal Breeding and Genomics, PO Box 338, 6700, AH, Wageningen, The Netherlands.

Received: 16 June 2017 Accepted: 8 April 2018

Published online: 12 April 2018

\section{References}

1. Schulz RW, Goos HJ. Puberty in male fish: concepts and recent developments with special reference to the African catfish (Clarias gariepinus). Aquaculture. 1999;177:5-12.

2. Zanuy S, Carrillo M, Mateos J, Trudeau V, Kah O. Effects of sustained administration of testosterone in pre-pubertal sea bass (Dicentrarchus labrax L). Aquaculture. 1999:177:21-35.

3. Okuzawa K. Puberty in teleosts. Fish Physiol Biochem. 2002;26:31-41.

4. Yaron Z, Levavi-Sivan B. Fish reproduction. Physiol Fishes. 2006:345-88.

5. Dufour S, Rousseau K. Neuroendocrinology of fish metamorphosis and puberty: evolutionary and ecophysiological perspectives. J Mar Sci Technol. 2007;15:55-68.

6. Nocillado JN, Elizur A. Neuroendocrine regulation of puberty in fish: insights from the grey mullet (Mugil cephalus) model. Mol Reprod Dev. 2008;75:355-61.

7. McClure CA, Hammell KL, Moore M, Dohoo IR, Burnley H. Risk factors for early sexual maturation in Atlantic salmon in seawater farms in New Brunswick and Nova Scotia, Canada. Aquaculture. 2007;272:370-9.

8. Ginés R, Afonso J, Argüello A, Zamorano M, Lopez J. Growth in adult gilthead sea bream (Sparus aurata $\mathrm{L}$ ) as a result of interference in sexual maturation by different photoperiod regimes. Aquac Res. 2003;34:73-83.

9. Weltzien F-A, Andersson E, Andersen Ø, Shalchian-Tabrizi K, Norberg B. The brain-pituitary-gonad axis in male teleosts, with special emphasis on flatfish (Pleuronectiformes). Comp Biochem Physiol A Mol Integr Physiol. 2004;137:447-77.

10. Almeida F, Lopes J, Crescencio R, Izel A, Chagas E, Boijink C. Early puberty of farmed tambaqui (Colossoma macropomum): Possible influence of male sexual maturation on harvest weight. Aquaculture. 2016;452:224-32.

11. Begtashi I, Rodríguez L, Moles G, Zanuy S, Carrillo M. Long-term exposure to continuous light inhibits precocity in juvenile male European sea bass (Dicentrarchus labrax, L.). I. Morphological aspects. Aquaculture. 2004;241:539-59.

12. Felip A, Zanuy S, Muriach B, Cerdá-Reverter JM, Carrillo M. Reduction of sexual maturation in male Dicentrarchus labrax by continuous light both before and during gametogenesis. Aquaculture. 2008;275:347-55.

13. Carrillo M, Begtashi I, Rodríguez L, Marin MC, Zanuy S. Long photoperiod on sea cages delays timing of first spermiation and enhances growth in male European sea bass (Dicentrarchus labrax). Aquaculture. 2010;299:157-64.

14. Felip A, Zanuy S, Carrillo M. Comparative analysis of growth performance and sperm motility between precocious and non-precocious males in the European sea bass (Dicentrarchus labrax, L.). Aquaculture. 2006;256:570-8.

15. Rodríguez L, Zanuy S, Carrillo M. Influence of daylength on the age at first maturity and somatic growth in male sea bass (Dicentrarchus labrax, L.). Aquaculture. 2001;196:159-75.

16. Rodríguez R, Felip A, Cerqueira V, Hala E, Zanuy S, Carrillo M. Identification of a photolabile period for reducing sexual maturation in juvenile male sea bass (Dicentrarchus labrax) by means of a continuous light regime. Aquac Int. 2012;20:1071-83.

17. Palstra AP, Crespo D, van den Thillart GE, Planas JV. Saving energy to fuel exercise: swimming suppresses oocyte development and downregulates ovarian transcriptomic response of rainbow trout Oncorhynchus mykiss. Am J Physiol Integr Comp Physiol. 2010;299:R486-99. 
18. Palstra AP, Schnabel D, Nieveen MC, Spaink HP, van den Thillart G. Swimming suppresses hepatic vitellogenesis in European female silver eels as shown by expression of the estrogen receptor 1, vitellogenin 1 and vitellogenin2 in the liver. Reprod Biol Endocrinol. 2010;8:1

19. Palstra AP, Schnabel D, Nieveen MC, Spaink HP, van den Thillart GE. Male silver eels mature by swimming. BMC Physiol. 2008:8:14.

20. Palstra AP, Planas JV. Fish under exercise. Fish Physiol Biochem. 2011;37:259-72

21. Brett JR. The respiratory metabolism and swimming performance of young sockeye salmon. J Fish Res Board Can. 1964;21:1183-226.

22. Palstra AP, Mes D, Kusters K, Roques JA, Flik G, Kloet K, et al. Forced sustained swimming exercise at optimal speed enhances growth of juvenile yellowtail kingfish (Seriola lalandi). Front Physiol. 2015;5:506.

23. Van Den Thillart G, Van Ginneken V, Körner F, Heijmans R, Van der Linden R, Gluvers A. Endurance swimming of European eel. J Fish Biol. 2004;65:312-8.

24. Palstra A, van Ginneken V, van den Thillart G. Cost of transport and optimal swimming speed in farmed and wild European silver eels (Anguilla anguilla). Comp Biochem Physiol A Mol Integr Physiol. 2008;151:37-44.

25. Bell WH, Terhune LDB. Water tunnel design for fisheries research. FishResBd CanTechRep. 1970;195:1-69.

26. Mayer P. Hematoxylin and eosin (H\&E) staining protocol. Mitt Zool Stn Neapel. 1896:12:303.

27. Lynch MJ, Raphael SS, Mcllor LD, Spare PD, Inwood MJ. Medical laboratory technology and clinical pathology. 2nd ed. W.B Saunders Company: Philadelphia, London, Toronto; 1969.

28. Barnabé G. Contribution a la connaissance de la biologie du loup, Dicentrarchus labrax (L.)(poisson Serranidae) de la region de Sete. Montpellier: These (Docteur es Sciences Naturelles) - Univ. des Sciences et Techniques du Languedoc fre; 1976.

29. Butts IAE, Baeza R, Støttrup JG, Krüger-Johnsen M, Jacobsen C, Pérez L, Asturiano JF, Tomkiewicz J. Impact of dietary fatty acids on muscle composition, liver lipids, milt composition and sperm performance in male European eel. Comp Biochem Physiol Part A. 2015;183:87-96.

30. Forne I, Castellana B, Marín-Juez R, Cerda J, Abián J, Planas JV. Transcriptional and proteomic profiling of flatfish (Solea senegalensis) spermatogenesis. Proteomics. 2011;11:2195-211.

31. Marín-Juez R, Castellana B, Manchado M, Planas JV. Molecular identification of genes involved in testicular steroid synthesis and characterization of the response to gonadotropic stimulation in the Senegalese sole (Solea senegalensis) testis. Gen Comp Endocrinol. 2011;172:130-9.

32. Crespo B, Gómez A, Mazón MJ, Carrillo M, Zanuy S. Isolation and characterization of Ff1 and Gsdf family genes in European sea bass and identification of early gonadal markers of precocious puberty in males. Gen Comp Endocrinol. 2013;191:155-67.

33. Shibata Y, Paul-Prasanth B, Suzuki A, Usami T, Nakamoto M, Matsuda M, et al. Expression of gonadal soma derived factor (GSDF) is spatially and temporally correlated with early testicular differentiation in medaka. Gene Expr Patterns. 2010:10:283-9.

34. Nicholls PK, Harrison CA, Gilchrist RB, Farnworth PG, Stanton PG. Growth differentiation factor 9 is a germ cell regulator of Sertoli cell function. Endocrinology. 2009;150:2481-90

35. Reinecke M. Insulin-like growth factors and fish reproduction. Biol Reprod. 2009;82:656-61.

36. Eijpe M, Heyting C, Gross B, Jessberger R. Association of mammalian SMC1 and SMC3 proteins with meiotic chromosomes and synaptonemal complexes. J Cell Sci. 2000;113(Pt 4):673-82.

37. Sambroni E, Rolland AD, Lareyre JJ, Le Gac F. FSH and LH have common and distinct effects on gene expression in rainbow trout testis. J Mol Endocrinol. 2012:50:1-18.

38. Sambroni E, Lareyre J-J, Le Gac F. Fsh controls gene expression in fish both independently of and through steroid mediation. PLoS One. 2013; 8:e76684.

39. Rocha A, Gómez A, Zanuy S, Cerdá-Reverter JM, Carrillo M. Molecular characterization of two sea bass gonadotropin receptors: CDNA cloning, expression analysis, and functional activity. Mol Cell Endocrinol. 2007;272:63-76.

40. Díaz N, Piferrer F. Lasting effects of early exposure to temperature on the gonadal transcriptome at the time of sex differentiation in the European sea bass, a fish with mixed genetic and environmental sex determination. BMC Genomics. 2015;16:679.
41. Varsamos S, Xuereb B, Commes T, Flik G, Spanings-Pierrot C. Pituitary hormone mRNA expression in European sea bass Dicentrarchus labrax in seawater and following acclimation to fresh water. J Endocrinol. 2006;191:473-80.

42. Vandesompele J, De Preter K, Pattyn F, Poppe B, Van Roy N, De Paepe A, et al. Accurate normalization of real-time quantitative RT-PCR data by geometric averaging of multiple internal control genes. Genome Biol. 2002;3:1.

43. Fulton TW. Rate of growth of sea fishes. Neill \& Company: Edinburgh; 1902.

44. Claireaux G, Couturier C, Groison AL. Effect of temperature on maximum swimming speed and cost of transport in juvenile European sea bass (Dicentrarchus labrax). J Exp Biol. 2006:209:3420-8.

45. Castro V, Grisdale-Helland B, Helland SJ, Kristensen T, Jørgensen SM, Helgerud J, et al. Aerobic training stimulates growth and promotes disease resistance in Atlantic salmon (Salmo salar). Comp Biochem Physiol A Mol Integr Physiol. 2011:160:278-90.

46. Herbert N. Practical aspects of induced exercise in finfish aquaculture. In: Palstra AP, Planas JV, editors. Swimming Physiology of Fish. Heidelberg: Springer; 2013.

47. Rodríguez L, Begtashi I, Zanuy S, Carrillo M. Long-term exposure to continuous light inhibits precocity in European male sea bass (Dicentrarchus labrax, L.): hormonal aspects. Gen Comp Endocrinol. 2005;140:116-25.

48. Schulz RW, De França LR, Lareyre J-J, LeGac F, Chiarini-Garcia H, Nobrega $\mathrm{RH}$, et al. Spermatogenesis in fish. Gen Comp Endocrinol. 2010;165:390-411.

49. Mazon MJ, Gomez A, Yilmaz O, Carrillo M, Zanuy S. Administration of follicle-stimulating hormone in vivo triggers testicular recrudescence of juvenile European sea bass (Dicentrarchus labrax). Biol Reprod. 2014;90:6.

50. García-López Á, de Jonge H, Nóbrega RH, de Waal PP, van Dijk W, Hemrika W, et al. Studies in zebrafish reveal unusual cellular expression patterns of gonadotropin receptor messenger ribonucleic acids in the testis and unexpected functional differentiation of the gonadotropins. Endocrinology. 2010;151:2349-60

51. García-López Á, Sánchez-Amaya Ml, Prat F. Targeted gene expression profiling in European sea bass (Dicentrarchus labrax, L.) follicles from primary growth to late vitellogenesis. Comp Biochem Physiol A Mol Integr Physiol. 2011;160:374-80.

52. Chauvigne F, Verdura S, Mazon MJ, Duncan N, Zanuy S, Gomez A, et al. Follicle-stimulating hormone and luteinizing hormone mediate the androgenic pathway in Leydig cells of an evolutionary advanced teleost. Biol Reprod. 2012;87:35.

53. Molés G, Gómez A, Rocha A, Carrillo M, Zanuy S. Purification and characterization of follicle-stimulating hormone from pituitary glands of sea bass (Dicentrarchus labrax). Gen Comp Endocrinol. 2008;158:68-76.

54. Zohar Y, Muñoz-Cueto JA, Elizur A, Kah O. Neuroendocrinology of reproduction in teleost fish. Gen Comp Endocrinol. 2010;165:438-55.

55. Yaron Z, Levavi-Sivan B. Endocrine regulation of fish reproduction. Encycl Fish Physiol Genome Environ. 2011;2:1500-8.

56. Norris DO, Carr JA. Vertebrate endocrinology. 5th ed. Oxford: Elsevier; 2013.

57. Chauvigné F, Verdura S, Mazón MJ, Boj M, Zanuy S, Gómez A, et al. Development of a flatfish-specific enzyme-linked immunosorbent assay for Fsh using a recombinant chimeric gonadotropin. Gen Comp Endocrinol. 2015:221:75-85.

58. Schulz RW, Miura T. Spermatogenesis and its endocrine regulation. Fish Physiol Biochem. 2002;26:43-56.

59. Miura T, Yamauchi K, Takahashi H, Nagahama Y. Hormonal induction of all stages of spermatogenesis in vitro in the male Japanese eel (Anguilla japonica). Proc Natl Acad Sci U S A. 1991;88:5774-8.

60. Vinas J, Piferrer F. Stage-specific gene expression during fish spermatogenesis as determined by laser-capture microdissection and quantitative-PCR in sea bass (Dicentrarchus labrax) gonads. Biol Reprod. 2008;79:738-47.

61. Molés G, Gómez A, Carrillo M, Zanuy S. Development of a homologous enzyme-linked immunosorbent assay for European sea bass FSH. Reproductive cycle plasma levels in both sexes and in yearling precocious and non-precocious males. Gen Comp Endocrinol. 2012;176:70-8.

62. Miura T, Miura C, Ohta T, Nader MR, Todo T, Yamauchi K. Estradiol-17ß stimulates the renewal of spermatogonial stem cells in males. Biochem Biophys Res Commun. 1999;264:230-4.

63. Chen J, Hu W, Zhu Z. Progress in studies of fish reproductive development regulation. Chin Sci Bull. 2013;58:7-16.

64. Blázquez M, González A, Papadaki M, Mylonas C, Piferrer F. Sex-related changes in estrogen receptors and aromatase gene expression and 
enzymatic activity during early development and sex differentiation in the European sea bass (Dicentrarchus labrax). Gen Comp Endocrinol. 2008;158:95-101.

65. Chauvigne F, Zapater C, Crespo D, Planas JV, Cerda J. Fsh and Lh direct conserved and specific pathways during flatfish semicystic spermatogenesis. J Mol Endocrinol. 2014;53:175-90.

66. Sawatari E, Shikina S, Takeuchi T, Yoshizaki G. A novel transforming growth factor- $\beta$ superfamily member expressed in gonadal somatic cells enhances primordial germ cell and spermatogonial proliferation in rainbow trout (Oncorhynchus mykiss). Dev Biol. 2007;301:266-75.

67. Mather JP, Attie KM, Woodruff TK, Rice GC, Phillips DM. Activin stimulates spermatogonial proliferation in germ-Sertoli cell cocultures from immature rat testis. Endocrinology. 1990;127:3206-14.

68. Miura T, Miura C, Yamauchi K, Nagahama Y. Human recombinant activin induces proliferation of spermatogonia in vitro in the Japanese eel Anguilla japonica. Fish Sci. 1995;61:434-7.

69. Rolland AD, Lardenois A, Goupil A-S, Lareyre J-J, Houlgatte R, Chalmel F, et al. Profiling of androgen response in rainbow trout pubertal testis: relevance to male gonad development and spermatogenesis. PLoS One. 2013;8:e53302

70. Dufour S, Sebert M, Weltzien F, Rousseau K, Pasqualini C. Neuroendocrine control by dopamine of teleost reproduction. J Fish Biol. 2010;76:129-60.

71. Blázquez M, Bosma P, Fraser E, Van Look K, Trudeau V. Fish as models for the neuroendocrine regulation of reproduction and growth. Comp Biochem Physiol C Pharmacol Toxicol Endocrinol. 1998;1 19:345-64.

72. Yaron Z, Gur G, Melamed P, Rosenfeld H, Elizur A, Levavi-Sivan B. Regulation of fish gonadotropins. Int Rev Cytol. 2003;225:131-85.

73. Planas JV, Swanson P, Rocha M, Arukwe A, Kapoor B. Physiological function of gonadotropins in fish. Fish Reprod Publ. 2008:37-66.

74. Munro A. The effects of apomorphine, d-amphetamine and chlorpromazine on the aggressiveness of isolated Aequidens pulcher (Teleostei, Cichlidae). Psychopharmacology. 1986;88:124-8.

75. Mok E-M, Munro A. Effects of dopaminergic drugs on locomotor activity in teleost fish of the genus Oreochromis (Cichlidae): involvement of the telencephalon. Physiol Behav. 1998:64:227-34

76. Weltzien F-A, Pasqualini C, Sébert M-E, Vidal B, Le Belle N, Kah O, et al. Androgen-dependent stimulation of brain dopaminergic systems in the female European eel (Anguilla anguilla). Endocrinology. 2006;147:2964-73.

77. Peyon P, Zanuy S, Carrillo M. Action of leptin on in vitro luteinizing hormone release in the European sea bass (Dicentrarchus labrax). Biol Reprod. 2001;65:1573-8.

\section{Ready to submit your research? Choose BMC and benefit from:}

- fast, convenient online submission

- thorough peer review by experienced researchers in your field

- rapid publication on acceptance

- support for research data, including large and complex data types

- gold Open Access which fosters wider collaboration and increased citations - maximum visibility for your research: over $100 \mathrm{M}$ website views per year

At BMC, research is always in progress.

Learn more biomedcentral.com/submissions 